\title{
Environmental and socioeconomic impact of cage aquaculture at Kpeve Tornu section of the Volta Lake, Ghana
}

\author{
VIDZRO FRANCIS MENSAH, TED YEMOH ANNANG", BENJAMIN D. OFORI"ฯ \\ Institute for Environmental and Sanitation Studies, University of Ghana, Legon. `email: tyannang@ug.edu.gh, ${ }^{\vee}$ bdofori@ug.edu.gh; \\ bdofori@staff.ug.edu.gh
}

Manuscript received: 4 August 2018. Revision accepted: 29 November 2018.

\begin{abstract}
Mensah VF, Annang TY, Ofori BD. 2018. Environmental and socioeconomic impact of cage aquaculture at Kpeve Tornu section of the Volta Lake. Bonorowo Wetlands 8: 84-95. Sufficient data on the financial viability of cage aquaculture in Ghana is limited. Little is also known about the effects of fish farming on the Volta Lake on fishing communities. This study, therefore, sought to investigate these relevant issues at Kpeve Tornu, a fishing society in Afadjato South District in the Volta Region. Laboratory analysis of physicochemical parameters suggested no significant differences between water quality parameters from four fish farms and two control locations. A cost-benefit analysis performed on five cages of volume 360 cubic meters each was 1.34 in the first production cycle. In contrast, a gross margin of 104.41 percent in the second production cycle suggests that the cage aquaculture industry in Ghana was financially viable. The cage aquaculture industry also positively impacted the livelihoods of Kpeve Tornu in regions of recruitment, poverty alleviation, trade, and food security. Cage fish farm owners did not comply fully with aquaculture rules. Aquaculture rules were effective on fingerlings and aquaculture-related chemicals producers. Still, the regulations on fish farmers needed a review because there were no definitions for intensive and semi-intensive fish farming in the aquaculture rules of Ghana.
\end{abstract}

Keywords: cage aquaculture, environment impact, socioeconomic impact, Volta Lake

\section{INTRODUCTION}

Cage culture is described by Bocek (n.d.) as the process of raising fish in an enclosed container that keeps the fish in an existing water body while allowing water exchange and waste removal into the surrounding water body. Beveridge (1987) stated that the environmental impacts of cage culture are often ignored and rarely subjected to research or investigation.

In Ghana, cage culture plays an increasingly important role in fish production, involving many small-scale farmers, private individuals, private companies, investors, and local institutions. Aquaculture has contributed significantly to the economy of Ghana. Ten percent of the population is predicted to be involved in the fishing industry from urban and rural regions where women dominate the post-harvest activities (FAO 2005). Although most cage farmers operate on a small scale, farmers consider aquaculture a source of income. Hence, fish produced are mainly sold instead of consumed by their family.

Fish farming in floating cages affected water quality. Phuong (1998) reported that cultured cage fish are entirely dependent on formulated diet, and the waste produced from this consumption is dumped directly into the water body. Consequently, Pillay (1992) reported that cage culture contributes nutrients, organic matter (Biochemical Oxygen Demand), and turbidity, which results in the deterioration of the quality of water and biota downstream. Considering that formulated feed is relative to a considerable carbohydrate and protein level, nutrient loading from the culture of Nile tilapia waste is thought to be high in cages. Debris such as organic matter, particulate matter, and suspended solids may result in significant massive sediment accumulation and Biochemical Oxygen Demand around the location of cage culture systems (Ali et al. 2006).

As a consequence of rapid expansion in the cage culture project in the Kpeve Tornu section of the Volta Lake, water quality was concerned to have deteriorated to affect other lake users in the region. The establishment of fish cages at the Kpeve Tornu region of the Volta Lake raised concerns about water pollution since most of the people of the host society relied on the same water source for drinking, washing, cooking, fishing, fishing transportation, and entertainment. Another notable point is that the Kpeve Headwork, a Ghana Urban Water Company facility, takes water from the surrounding cage culture region to treat consumers in four different administrative districts in the Volta Region.

This study aims at achieving four main specific objectives, i.e., (i) Assess the level of pollutants from fish cages into the lake. (ii) Predict the cost and returns (costbenefit ratio and gross margin) related to the cage culture industry in the first and second production cycles, respectively. (iii) Evaluate the socioeconomic impacts of the cage culture project on the livelihoods of people in Kpeve Tornu Society. (iv) Assess the compliance levels of fish farmers with aquaculture rules. 


\section{MATERIALS AND METHODS}

\section{The study area}

The profile of the Kpeve Tornu community

Kpeve Tornu is located on an inlet of the Volta Lake at the south-eastern part of Afadjato South District in the Volta Region of Ghana. This small fishing society is most conspicuous with physical features of the region are the Akwapim-Togo-Atakora ranges, which made the eastern boundaries between Afadjato South and Ho West Districts, south of latitude $3.028^{\prime} \mathrm{N}$.

The majority of the people participate in fishing activities for their livelihood, while few participate in trading and peasant farming. The people's livelihoods primarily relied on the Volta Lake because it was their primary water source for drinking, washing, cooking, fishing, recreation, and others.

\section{Assessing water quality parameters}

Water samples were taken at six locations in the cage culture region; four fish farms, and two non-caged regions 800 meters upstream and downstream of the cage region (as control locations) for laboratory analyses and comparison of the level of ammonia, suspended solids, total phosphorus, total nitrogen, copper, dissolved solids and organic matter following standard methods. Dissolved oxygen (DO), turbidity, conductivity, $\mathrm{pH}$, and temperature were measured during the data acquisition. The selection of the distance of control locations was based on research findings. The environmental effect of cage culture on sedimentation (Nash 2001; Carrol et al. 2003) and water quality (Guo and Li 2003) are mostly limited to within $50 \mathrm{~m}$.

Water samples were obtained at two months intervals (from December 2013 to April 2014). Four cages were chosen randomly as a representative sample of the cage culture region and two control locations. Three water samples were obtained from each location and then measured, and the average values were calculated for each part. The results from the six sampling locations were compared to define any significant differences.

Sterilized containers were used to prevent contamination of samples during sampling, handling, and storage, and working conditions were carefully chosen. Water samples were collected at each sampling location into a plastic bucket for in-situ measurements of temperature, $\mathrm{pH}$, conductivity, and total dissolved solids were recorded insitu using HANNA Temp/pH/EC/TDS meter (Model HI 99301). The DO was measured using a DO meter (Model Milwaukee MW600). Turbidity was determined using $\mathrm{HACH}$ 2100P turbidimeter and the reading recorded in Nephelometric Turbidity Units (NTU). Fieldwork was conducted between $7.00 \mathrm{am}$, and $8.00 \mathrm{am}$ on each sampling day.

\section{Laboratory analysis}

A 1.5-liter pre-treated plastic container filled with water at each sampling location was kept on ice in an ice chest before transporting them to the laboratory. This water was subsequently used in the laboratory for ex-situ analysis. Water samples that were not analyzed immediately were stored in a refrigerator below $4{ }^{\circ} \mathrm{C}$. The samples must be analyzed within five days to avoid inaccuracy.

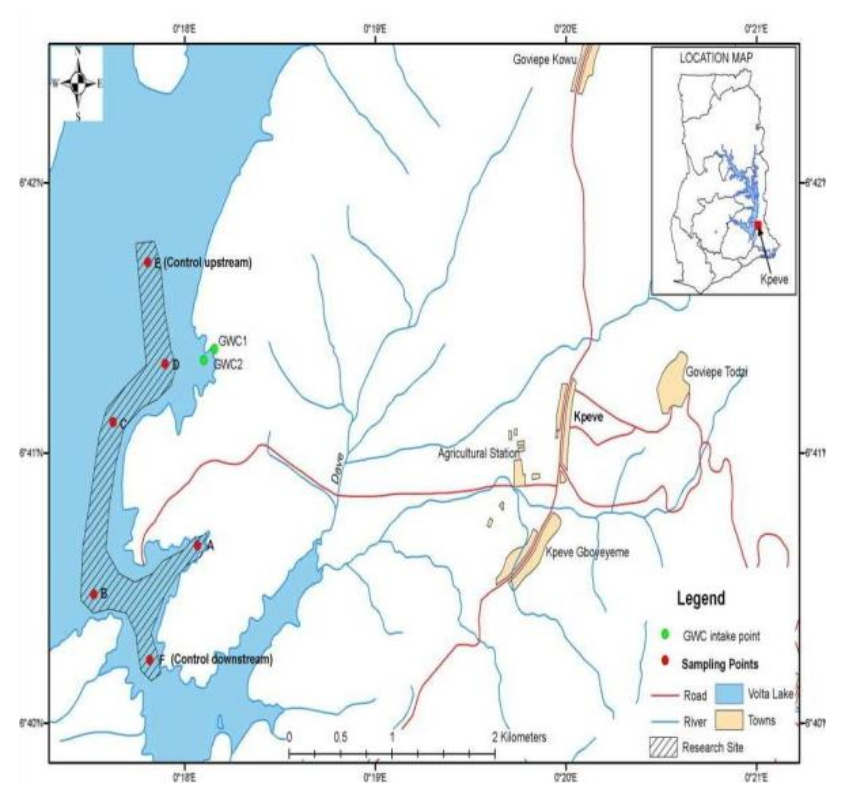

Figure 1. A map shows the Kpeve Tornu section of the Volta Lake and water sampling locations. Source: Department of Geography and Resource Development, University of Ghana, Accra (2014)

The chemical properties of the water samples were evaluated at the Ecological Laboratory of the Institute for Environment and Sanitation Studies, University of Ghana. The parameters defined were as follows: nitrate-nitrogen, phosphate, copper, ammonia-nitrogen, total suspended solids, organic matter (BOD). The analysis was carried out using a HACH DR/2010 UV Spectrophotometer. All the laboratory measurements were performed following standard methods (APHA 1998; WHO 1989 and UNESCO/WHO 1978).

Approximately $500 \mathrm{ml}$ of water sample was stirred for precisely 2 minutes, then poured into a one-liter beaker stirred, and $25 \mathrm{ml}$ aliquots were poured into a sample cell prepared. The sample was swirled, and the reading was recorded with a spectrophotometer set at $810 \mathrm{~nm}$, which has previously been calibrated using $25 \mathrm{ml}$ of demineralized water as the blank.

The turbidity of the samples $(15 \mathrm{ml})$ was calculated using a portable turbidimeter (Model 2100P).

The 5-day BOD test was employed, consisting of filling with sample an airtight bottle of the specified size and incubating it at a specific temperature for five days. DO was measured initially after incubation, and the BOD was computed from the difference between the initial and final DO (APHA 1995).

The nitrate amounts in each sample were measured using nitrate powder pillows in a direct reading Hach Spectrophotometer (Model DR. 2010). Twenty-five milliliters of the sample were weighed into the sample cell. One Nitraver 5 Nitrate Reagent Powder Pillow was applied to the sample and vigorously shaken for 1 minute. The solution was permitted to react for 5 minutes, after which another cell was filled with $25 \mathrm{ml}$ of only the sample (blank). After 5 minutes, the blank sample was placed in the spectrophotometer for calibration (zeroing). The 
prepared sample was then transferred to the cell holder to determine the nitrate level at $500 \mathrm{~nm}$. The sample cell was filled with $25 \mathrm{ml}$ of sample, and one Phos Ver 3 Phosphate Powder Pillow reagent was applied to the cell content and swirled immediately for two minutes. Another sample cell (serving as the blank) was filled with $25 \mathrm{ml}$ of sample and put into the cell holder to calibrate it. The level of phosphorus was determined at $890 \mathrm{~nm}$. One hundred $\mathrm{ml}$ of the sample was moved into a clean $250 \mathrm{ml}$ Erlenmeyer flask. The contents of one chloride 2 Indicator Powder Pillows were applied and swirled to mix. The delivery tube tip was placed into the solution, and the flask swirled while titrating with silver nitrate from a yellow to red-brown obtained.

Powder Pillows were used to measure copper levels in a direct reading Hach spectrophotometer (Model DR. 2000). Ten milliliters of the sample were weighed into the sample cell. One $\mathrm{Cu}$ Ver I Copper Reagent Powder Pillow was poured into the sample cell then swirled to mix. The solution was allowed to react for 2 minutes, then $10 \mathrm{ml}$ of the sample was added. Then the prepared sample was put into the cell holder of the spectrophotometer to determine the copper level at $560 \mathrm{~nm}$ (Hach Company, 2001a).

\section{Assessment of financial viability of cage aquaculture}

Primary benefit-cost ratio analysis was done to determine the economic feasibility of the cage culture project. The benefit-cost ratio was acquired by dividing the returns (sales) by the total cost of production (fixed cost and variable cost).

\section{Benefit-Cost Ratio $=\underline{\text { Returns on investment }}$ Total cost of production}

The first production cycle predicted the primary benefit-cost ratio analysis to incorporate the cost incurred on fixed inputs. The gross margin was acquired by subtracting the variable cost from returns on investment by estimation during the second production cycle. Five cages were used to gather data on value and profits for the two production cycles. We modified an approved framework for the data collection and estimation on the financial viability of cage aquaculture in Ghana. This framework was designed by the Water Research Institute (Ghana) in 2009 in collaboration with the World Fish Center in Malaysia (Ofori et al. 2009).

Five entities included in the aquaculture industry in the region were chosen to represent various industry interests and provide relevant information to establish financial inputs and gains using a designed framework. The selection criterion was based on bookkeeping records. The industry interests were Partnership (Catchrite Farms), Sole Proprietorship (3 'As' Agri Solutions), Direct Foreign Investor (Worldings Investment Ghana Limited), Training and Consultancy (Global Agricultural Foundations), and the Best Farmer-Based Organization in Ghana (2013) namely Volta Lake Fish Farmers Association.

\section{Assessment of the impact of cage culture business on the livelihoods of the people of Kpeve Tornu}

Twenty-five percent of the adult population was selected from the fish farming society to assess the people's knowledge on the impacts of the cage culture projects. One hundred and three respondents were chosen because Kpeve Tornu was estimated to be 763 with an adult population of 412 based on the district adult population rate in September 2013. Gender issues were considered in the selection process as $51.5 \%$ of the respondents were women, and $48.5 \%$ were male during the interview process. The quota sampling used was according to the composition of males and females in the district population estimates.

The questionnaire designed to gather relevant information was tested on twenty-one society members for modification. Data collected included the impact of cage farming activities on (1) fishing activities in the society, (2) water transport, (3) job, (4) cultural values, and (5) other relevant social activities.

Socioeconomic characteristics and compliance rules of fish farmers socioeconomic aspects of eighteen randomly selected cage farmers out of twenty-nine known farmers were interviewed to obtain relevant information. Relevant environmental rules and documents concerning the fish farming projects were investigated. Notable among them were the Fisheries Act of 2002 (Act 625), Environmental Protection Agency Act, 1994 (Act 490), Environmental Rules Assessment, 1999, (LI 1652), Public Health Act of 2012 (Act 851), Aquaculture Rules of Ghana, 2010 (LI 1968), and the Abuja Declaration on Sustainable Fisheries and Aquaculture in Africa.

\section{Statistical data gathering and analysis}

Fieldworks were carried out between December 2013 and April 2014, when the people in the society relied on most on the Volta Lake for livelihood opportunities like fishing and farming. All relevant quantitative data on water quality parameters and also to generate data presentation were stored in Microsoft Excel. The data were DO, BOD, turbidity, conductivity, suspended solids, dissolved solids, $\mathrm{pH}$, copper, nitrate, ammonia, phosphate, and temperature.

Recorded measurements from the field were statistically analyzed using the Statistical Package for Social Scientists (SPSS) software package (version 20.0). The survey was coded and built on SPSS to generate figures, graphs, tables, differences in water quality parameters, and the socioeconomic background of fish farmers besides people living in Kpeve Tornu.

Data collected on water quality parameters were analyzed using the SPSS Software Programme (version 20.0). The significant differences were calculated at the probability of 0.05. A Global Positioning System (GPS) Model was used to point the coordinates of the sampling locations and generate the study region map. 


\section{RESULTS AND DISCUSSION}

\section{Water quality parameters}

The average values for the sampling locations were $\mathrm{A}$ $0.77 \mathrm{mg} / \mathrm{L}$, B $0.6 \mathrm{mg} / \mathrm{L}, \mathrm{C} 0.66 \mathrm{mg} / \mathrm{L}, \mathrm{D} 0.47 \mathrm{mg} / \mathrm{L}$, control upstream $0.93 \mathrm{mg} / \mathrm{L}$ and control downstream $0.53 \mathrm{mg} / \mathrm{L}$ (Figure 2).

Figure 3 displays the average values for phosphate level at the sampling locations were A $(1.93 \mathrm{mg} / \mathrm{L}), \mathrm{B}(1.04$ $\mathrm{mg} / \mathrm{L}), \mathrm{C}(1.24 \mathrm{mg} / \mathrm{L}), \mathrm{D}(1.02 \mathrm{mg} / \mathrm{L})$, control upstream $(0.93 \mathrm{mg} / \mathrm{L})$ and control downstream $(0.33 \mathrm{mg} / \mathrm{L})$.

Figure 4 shows the average values for the sampling locations s were A $0.067 \mathrm{mg} / \mathrm{L}$, B $0.083 \mathrm{mg} / \mathrm{L}, \mathrm{C} 0.04 \mathrm{mg} / \mathrm{L}$, D $0.07 \mathrm{mg} / \mathrm{L}$, control upstream $0.07 \mathrm{mg} / \mathrm{L}$ and control downstream $0.06 \mathrm{mg} / \mathrm{L}$.

DO levels varied in the study region in December 2013, with location B showing the lowest value of $3.21 \mathrm{mg} / \mathrm{L}$ and location D recording the highest amount of $4.1 \mathrm{mg} / \mathrm{L}$. Other measurements were A $3.5 \mathrm{mg} / \mathrm{L}$, B $3.92 \mathrm{mg} / \mathrm{L}$, control upstream $3.97 \mathrm{mg} / \mathrm{L}$ and control downstream $4.02 \mathrm{mg} / \mathrm{L}$. DO values ranged between $5.59 \mathrm{mg} / \mathrm{L}$ for location $\mathrm{B}$ and $6.2 \mathrm{mg} / \mathrm{L}$ for control downstream with locations $\mathrm{A}, \mathrm{C}, \mathrm{D}$, and control upstream recording $6.1 \mathrm{mg} / \mathrm{L}, 5.89 \mathrm{mg} / \mathrm{L}, 5.85$ $\mathrm{mg} / \mathrm{L}$, and $5.79 \mathrm{mg} / \mathrm{L}$, respectively in February 2014. DO levels in April, 2014 were A $6.9 \mathrm{mg} / \mathrm{L}$, B $7.9 \mathrm{mg} / \mathrm{L}, \mathrm{C} 7.5$ $\mathrm{mg} / \mathrm{L}$, D $7 \mathrm{mg} / \mathrm{L}$, control upstream $7.2 \mathrm{mg} / \mathrm{L}$, and control downstream $7.1 \mathrm{mg} / \mathrm{L}$. The average values for the sampling locations s for DO were A $5.5 \mathrm{mg} / \mathrm{L}$, B $5.6 \mathrm{mg} / \mathrm{L}$, C $5.8 \mathrm{mg} / \mathrm{L}$, D $5.7 \mathrm{mg} / \mathrm{L}$, control upstream $5.7 \mathrm{mg} / \mathrm{L}$, and control downstream $5.8 \mathrm{mg} / \mathrm{L}$ (Figure 5).

The average readings for the sampling locations s were A 7.5, B 7.4, C 7.8, D 7.4, control upstream 7.5, and power downstream 7.6 (Figure 6). The differences in the results were not significant, suggesting that the fish farming activities in the study region did not significantly affect water quality in the region.

The results suggest fluctuating figures in the BOD recorded at the study locations. However, it is notable that location A recorded the highest levels of BOD in the three months. The average values for 1.45 the sampling locations were A $1 . \mathrm{mg} / \mathrm{L}$, B $1.98 \mathrm{mg} / \mathrm{L}$, C $2.0 \mathrm{mg} / \mathrm{L}, \mathrm{D} \mathrm{mg} / \mathrm{L}$, control upstream $1.5 \mathrm{mg} / \mathrm{L}$ and control downstream 1.3 $\mathrm{mg} / \mathrm{L}$ (Figure 7).

The average values for the sampling locations were A 3.0 NTU, B 2.7 NTU, C 2.7 NTU, D 3.0 NTU, control upstream 2.3 NTU, and control downstream 2.3 NTU (Figure 8). This suggests that cage aquaculture slightly impacts turbidity in the study region, but this is of little significance. There were also no significant differences between fish cage locations and control locations.

Figure 9 shows the average values for the sampling locations were A $4.3 \mathrm{mg} / \mathrm{L}$, B $4.7 \mathrm{mg} / \mathrm{L}$, C $6.0 \mathrm{mg} / \mathrm{L}$, D $5.0 \mathrm{mg} / \mathrm{L}$, control upstream $5.7 \mathrm{mg} / \mathrm{L}$ and control downstream $5.0 \mathrm{mg} / \mathrm{L}$. The results suggest variety in the levels of suspended solids in the study region with time. Nevertheless, differences between sampled locations were not significant.

The average values as demonstrated in Figure 10 for the sampling locations were A $(33.3 \mathrm{mg} / \mathrm{L})$, B $(32.0 \mathrm{mg} / \mathrm{L}), \mathrm{C}$ (31.3mg/L), D (33.0mg/L), control upstream $(33.0 \mathrm{mg} / \mathrm{L})$ and control downstream (34.3mg/L). No significant differences (ANOVA; $\mathrm{P}<0.05$ ) were observed in the level of dissolved substances in the six sampled locations.

The average values for the sampling locations were A $69 \mu \mathrm{S} / \mathrm{cm}, \mathrm{B} 68 \mu \mathrm{S} / \mathrm{cm}, \mathrm{C} 68 \mu \mathrm{S} / \mathrm{cm}, \mathrm{D} 70 \mu \mathrm{S} / \mathrm{cm}$, control upstream $68 \mu \mathrm{S} / \mathrm{cm}$ and control downstream $70 \mu \mathrm{S} / \mathrm{cm}$ (Figure 11). Results suggest that differences in the electrical conductivity in the study region were not significant between December 2013 and April 2014.

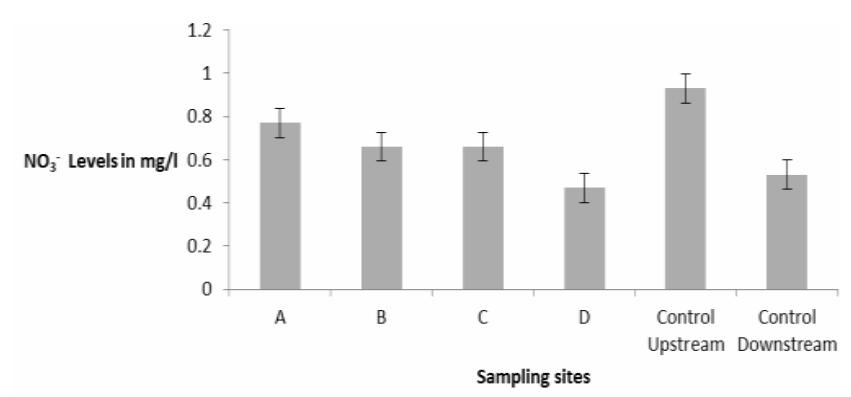

Figure 2. Graph showing variations in average nitrate values at the various sampling points

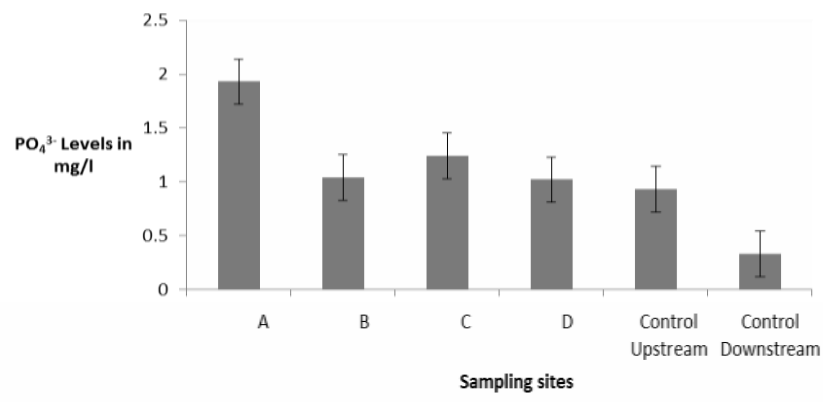

Figure 3. Graph showing the variations in average phosphate levels at the various sampling points

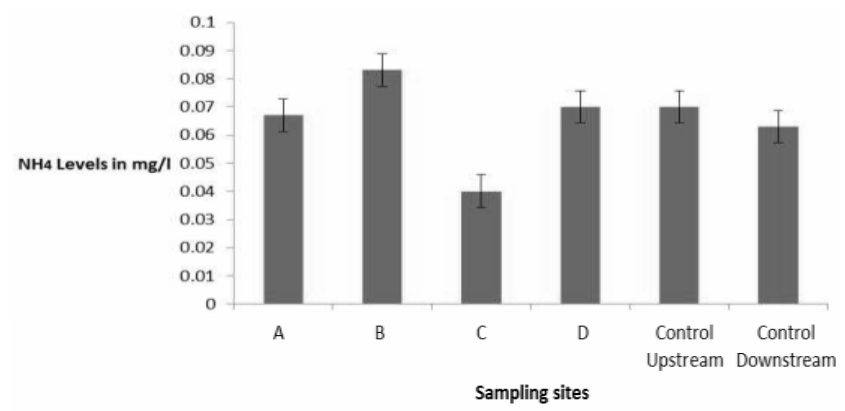

Figure 4. Graph showing variations in average ammonium levels at the various sampling points

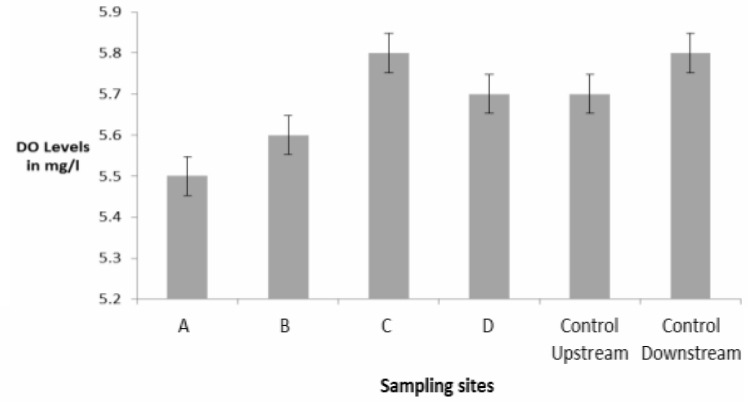

Figure 5. Graph showing variation in average dissolved oxygen levels at the various sampling points 


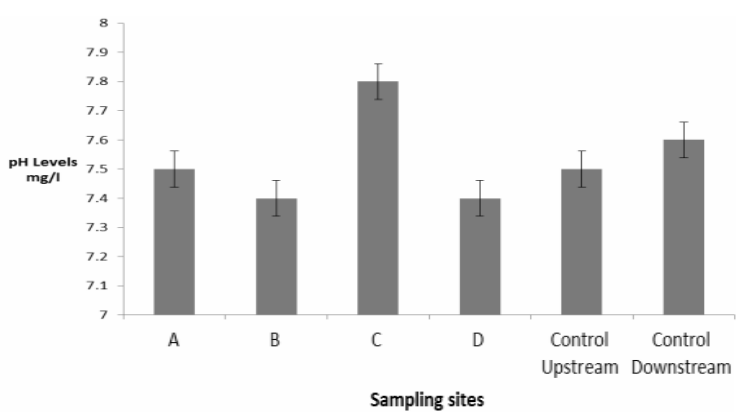

Figure 6. Graph showing variation in average $\mathrm{pH}$ levels at various sampling points

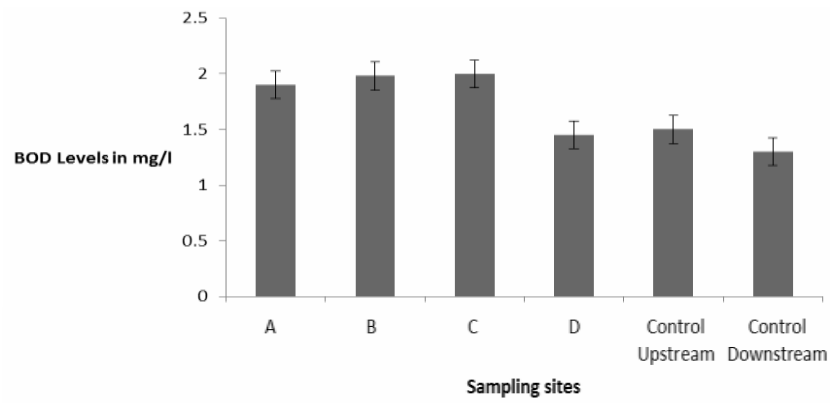

Figure 7. Graph showing variations in average BOD levels at the various sampling sites

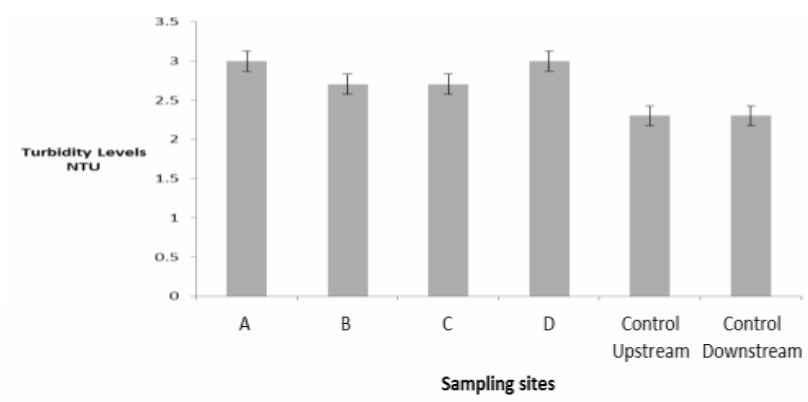

Figure 8. Graph showing variations in average turbidity levels at various sampling points

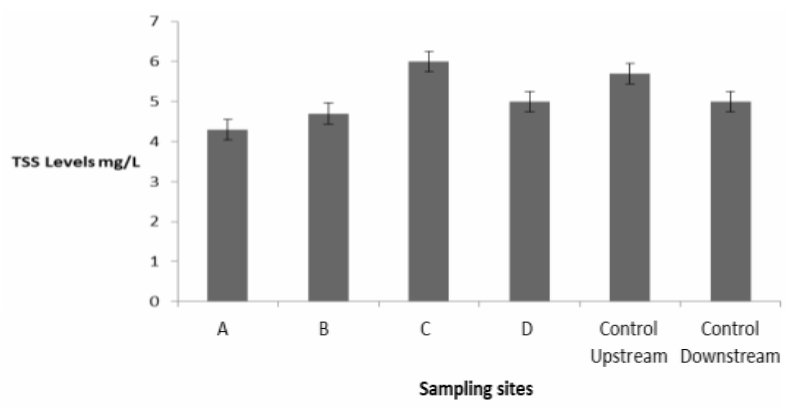

Figure 9. Graph showing variations in average suspended solids levels at the various sampling points

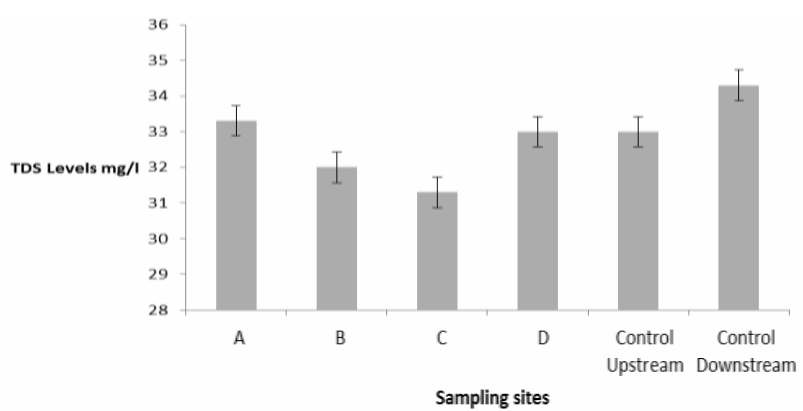

Figure 10. Graph showing variations in average total dissolved solids levels at the various sampling points

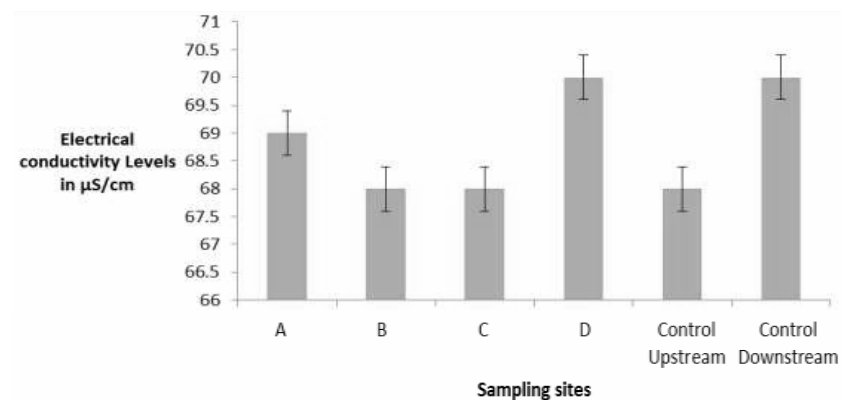

Figure 11. Graph showing variations in average conductivity levels at the various sampling sites

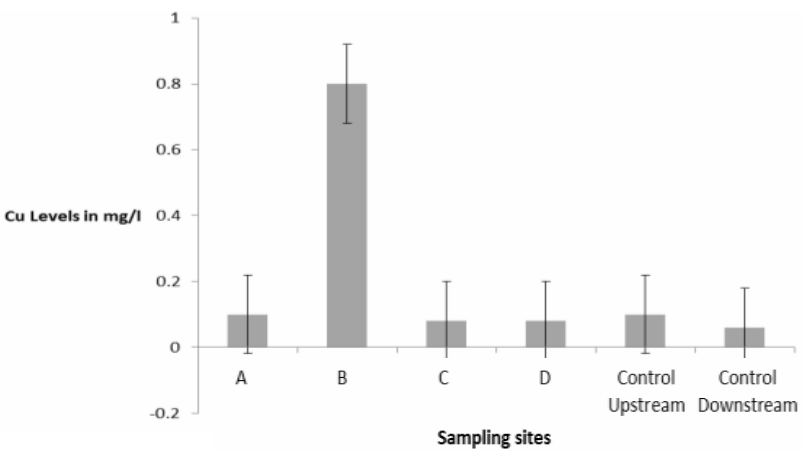

Figure 12. Graph showing variations in average copper levels at the various sampling sites

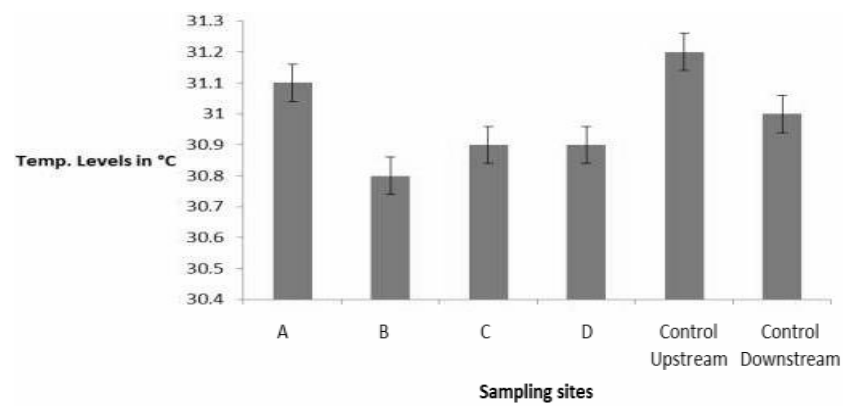

Figure 13. Graph showing variations in average temperature levels at the various sampling sites 
The average values for the sampling region were $\mathrm{A}$ $(0.1 \mathrm{mg} / \mathrm{L}), \quad$ B $(0.8 \mathrm{mg} / \mathrm{L}), \quad$ C $0.08 \mathrm{mg} / \mathrm{L}, \quad$ D $0.08 \mathrm{mg} / \mathrm{L}$, control upstream $0.1 \mathrm{mg} / \mathrm{L}$ and control downstream $0.06 \mathrm{mg} / \mathrm{L}$ (Figure 12). The results showed low levels of copper levels with no significant differences (ANOVA; P< 0.05 ) between sampling locations.

Figure 13 shows the average values for the sampling locations were A $\left(31.1^{\circ} \mathrm{C}\right), \mathrm{B}\left(30.8{ }^{\circ} \mathrm{C}\right), \mathrm{C}\left(30.9^{\circ} \mathrm{C}\right), \mathrm{D}$ $\left(30.9{ }^{\circ} \mathrm{C}\right)$, control upstream $\left(31.2{ }^{\circ} \mathrm{C}\right)$ and control downstream $\left(31.0{ }^{\circ} \mathrm{C}\right)$. The results suggest no significant differences between temperature levels at the six sampling locations, indicating that cage aquaculture activities do not affect water temperature levels in the study region.

Financial viability (cost-benefit ratio and gross margin) of cage aquaculture in the study area

The economic viability of an industry entity determines how economically sustainable the industry venture is. The cost-benefit ratio was calculated during the first production cycle, whereas the gross margin was computed in the second production cycle. Expenditure for the five selected industry entities in the study region for five single cages of size 360 cubic meters each fell between GHC 22,941.00 for Volta Lake Fish Farmers Association to GHC 51,625.00 for Global Agricultural Foundation. The average expenditure was 34,573.00. Revenue levels fell between GHC 28,800.00 and GHC 91,980.00 for Volta Lake Fish Farmers Association and Global Agricultural Foundation, respectively, with average revenue for the five industry entities of GHC 48,176.00. The average net income for the same period (January 2014) was GHC 13,603.00. The costbenefit ratio ranged between 1.11 for $3 \mathrm{~A}$ 'S Agri Solutions and 1.78 for Global Agricultural Foundation, and 1.34 on average. Table 1 shows returns on investment were $10.87 \%$ for 3 A'S Agri Solutions and $78.17 \%$ for Global Agricultural Foundation, with an average of $33.818 \%$ for the five industry entities.

The expected expenditure for the second production cycle for the next six months ranged from GHC 11,883.00 for Volta Lake Fish Farmers Association to GHC40,967.00 for Global Agricultural Foundation, an average expenditure for the five industry entities was GHC 23,506.00. Table 2 displays the average expected revenue was GHC 48,176.00 with an average net income of GHC 24,670.00. The average gross margin calculated in percentage was $104.41 \%$.

\section{Impact of cage aquaculture on the livelihood of people in fish farming communities \\ Socio-economic background of the people}

Fifty-one people representing $49.5 \%$ who fall within 18-35 years were interviewed, followed by thirty-five middle-aged people (36-59 years) representing 34\% and 17 older adults representing $16.5 \%$. The figures indicated a substantial youth population in the society. The Kpeve Tornu society is a settler society, and a few aged people may be leaving the town for their original homes.

Fifty males and fifty-three females were interviewed in the society. The ratio reflects the sex composition in the region. Thirty people randomly interviewed had no formal education, with thirty-five ending their knowledge at the primary school level. Twenty-nine of them have either attained or dropped out at the junior high school/middle school level. Nine of them, representing $7.8 \%$, reached or completed senior high or technical schools, and one person attained a tertiary level of education.

Table 1. Expenditure and returns on investment in the first production cycle (in GHC)

\begin{tabular}{lccccc}
\hline \multicolumn{1}{c}{ Business entity } & & \multicolumn{2}{c}{$\mathbf{1}^{\text {st }}$ production cycle (6 months) } & \\
& Expenditure & Revenue & CBR & Net Income & Returns (\%) \\
\hline 1. 3 A'S Agri Solutions & $31,118.00$ & $34,500.00$ & 1.11 & $3,382.00$ & 10.87 \\
2. Catchrite Farms Ltd. & $32,743.00$ & $39,600.00$ & 1.21 & $6,857.00$ & 20.94 \\
3. Global Agricultural Foundations & $51,625.00$ & $91,980.00$ & 1.78 & $40,355.00$ & 78.17 \\
4. Worlding Investment (GH) Ltd. & $34,438.00$ & $46,000.00$ & 1.36 & $11,562.00$ & 33.57 \\
5. Volta Lake Fish Farmers Association & $22,941.00$ & $28,800.00$ & 1.26 & $5,859.00$ & 25.54 \\
Average & $34,573.00$ & $48,176.00$ & 1.344 & $13,603.00$ & 33.818 \\
\hline
\end{tabular}

$(1 \mathrm{GHC}=$ US\$ 0.41623)

Table 2. Expenditure and returns on investment in the second production cycle (in GHC)

\begin{tabular}{|c|c|c|c|c|}
\hline \multirow{2}{*}{ Business entity } & \multicolumn{4}{|c|}{$2^{\text {nd }}$ Production Cycle (6 Months) } \\
\hline & Expenditure & Revenue & Net income & Gross margin \\
\hline 3 A'S Agri Solutions & $19,860.00$ & $34,500.00$ & $14,640.00$ & 73.72 \\
\hline Catchrite Farms Ltd. & $21,485.00$ & $39,600.00$ & $18,115.00$ & 84.31 \\
\hline Global Agricultural Foundations & $40,967.00$ & $91,980.00$ & $51,013.00$ & 124.52 \\
\hline Worlding Investment (GH) Lt. & $23,335.00$ & $46,000.00$ & $22,665.00$ & 97.13 \\
\hline Volta Lake Fish Farmers Association & $11,883.00$ & $28,800.00$ & $16,917.00$ & 142.36 \\
\hline Average & $23,506.00$ & $48,176.00$ & $24,670.00$ & 104.41 \\
\hline
\end{tabular}

$(1 \mathrm{GHC}=$ US\$ 0.41623) 
The economic activities of the people in the society were mainly trading (28.2\%), farming (19.4\%), fish farming (14.6\%), farming and fishing (5.8\%), fishing $(4.9 \%)$, fishing and fish farming $(4.9 \%)$, farming and fish farming $(3.9 \%)$, farming, farming and trading $(2.9 \%)$, fishing and fish farming (1.9\%). $10.7 \%$ of the people participated in other economic activities such as masonry, carpentry, and dressmaking. Only $2.9 \%$ of the people were unemployed. Most people are also involved in multiple economic activities. $64.1 \%$ of the people interviewed have stayed in the society for more than ten years, $12.6 \%$ of the interviewees have lived in the city for six to ten years. $21.4 \%$ of them have been in the city for one to five years, and less than $2 \%$ of the people interviewed lived in the town for less than one year. The figures indicated that a vast majority of the people $(64.1 \%)$ have stayed in the society for longer than ten years. There was also an influx of people into the city in the last five years, indicating an attraction of people towards the fish farming activities in the city since people who have stayed in the society between one to five years are more than those within six to ten years.

\section{Primary sources and uses of water in the community}

Table 3 shows that $9.7 \%$ of the people in the city depend solely on pipe-borne water while $19.4 \%$ rely on lake water. As many as $70.3 \%$ combine lake water and pipe-borne for various purposes.

Only $5.8 \%$ of the people in the society did not utilize the lake water for livelihood purposes. Water from the lake was used primarily for drinking, cooking, and washing $(94.2 \%)$. Figure 14 shows other uses, including water transport (84.4\% of the people), recreation $(25.2 \%)$, as well as a libation (traditional worship) (11.7\%), and irrigation $(2.9 \%)$

\section{Perception/Assessment of people on the impacts of cage aquaculture on their livelihood and water quality}

Table 4 shows that $93.2 \%$ of the people in the city have the perception that cage aquaculture did not affect their activities in the city. $6.8 \%$, however, the remaining thought they were affected by the cage aquaculture industry in the city.

One percent of the people thought cage aquaculture affected recreation, while another $1 \%$ believed that aquaculture adversely affected fishing activities close to society. The following response indicates that the majority of the people thought the environment was not negatively affected by fish farming in floating cages (Table 5).

The people's assessment of the attitude of fish farmers toward the water environment in the area were as follows: proper $(64.1 \%)$, average $(8.7 \%)$ and poor $(13.7 \%)$, and $13.7 \%$ of the people were not sure as to whether the fish farmers handled the environment well or not. The majority of the respondents seemed to be satisfied with the way fish farmers dealt with the lake water during their farming activities.

\section{Benefits of cage aquaculture to the society}

The respondents agreed that fish farming has dramatically improved living conditions in the city, particularly in employment, revenue, food, and trade regions. This implies that the cage aquaculture industry has positively impacted people's livelihood. Women in society benefitted more than the men from cage farming activities since they are highly employed to assist in harvesting activities than men.

From Table 15, $43.7 \%$ of the people interviewed did not benefit directly from the cage aquaculture industry in society. The rest have direct benefits from fish farming activities. $4.9 \%$ gained from casual employment, food, income, and fish trade. $6.8 \%$ benefited from the fish trade. $27.2 \%$ benefited from permanent employment, income, and food. $17.5 \%$ gained from casual jobs, income, and food.

The respondents requested livelihood assistance from fish farm owners to increase their living conditions, including the establishment of more fish farms in the region (33\%), health facilities $(18.4 \%)$, support for educational projects $(16.5 \%)$, and road construction $(11.7 \%)$. Three female respondents also asked for the employment of females in permanent fish farming jobs such as the feeding of fish in cages and diving to mend fishnets. A few respondents $(6.8 \%)$ called on fish farm owners to be law-abiding and avoid chemical usage. The rest $(10.7 \%)$ had no idea what fish farmers should do to help their society.

Table 3. Main sources of water for the people in the community

\begin{tabular}{lcc}
\hline \multicolumn{1}{c}{ Main sources of water } & $\begin{array}{c}\text { Frequency } \\
\text { (No. of people) }\end{array}$ & Percent (\%) \\
\hline Pipe-borne water & 10 & 9.7 \\
Lake water & 20 & 19.4 \\
Pipe-borne and lake water & 73 & 70.9 \\
Total & 103 & 100.0 \\
\hline
\end{tabular}

Table 4. Assessment respondents on the negative impact of cage aquaculture on livelihood opportunities

\begin{tabular}{lcc}
\hline Response & Frequency & Percent $(\boldsymbol{\%})$ \\
\hline Yes & 7 & 6.8 \\
No & 96 & 93.2 \\
Total & 103 & 100.0 \\
\hline
\end{tabular}

Table 5. Perception of people on whether cage aquaculture causes pollution

\begin{tabular}{lcc}
\hline Response & Frequency & Percent $(\boldsymbol{\%})$ \\
\hline Yes & 19 & 18.4 \\
No & 68 & 66.0 \\
Not certain & 16 & 15.5 \\
Total & 103 & 100.0 \\
\hline
\end{tabular}

Table 6. Registration of fish farmers in the study area

\begin{tabular}{lcc}
\hline Registration of business & Frequency & Percent $(\boldsymbol{\%})$ \\
\hline Yes & 10 & 55.6 \\
No & 8 & 44.4 \\
Total & 18 & 100.0 \\
\hline
\end{tabular}




\section{Aquaculture regulations and compliance levels of fish farm owners}

Not all fish farmers have registered their industry entity. The fish farming industry's income varies since the industry is capital intensive. Compliance with aquaculture rules by fish farmers has not been encouraging.

\section{Socio-economic background of cage farm owners in the study region}

All the fish farm owners in the study region interviewed were males. The results indicated that most fish farmers in the region are highly educated -industry. All the farm owners in the study region engaged in other economic activities apart from fish farming. Fish farming, therefore, was their secondary economic activity. $50 \%$ of the fish farm owners were government workers, while the rest were self-employed.

\section{Registration of fish farming industry in the study region}

Ten out of the eighteen respondents have registered their industry entities with various authorities such as the Local Assemblies, the Registrar General's Department, and the Fisheries Commission. Table 6 shows that eight of them have not registered their industries. The data implies that some fish farms in the study region were operating without registration and that some of these fish farmers were not following rules on aquaculture in Ghana.

\section{Primary sources of capital for fish farming business in the study area}

Fish farmers combined three different funding sources in their market (Table 16). Four of them depend solely on personal savings; two rely only on bank loans. Two others combine personal savings and bank loans. Six of them enter into an industry partnership with their savings, while four combine personal savings and bank loans and are in an industry partnership (Figure 16).

\section{Financial viability of cage aquaculture industry in the study region}

All the fish farm owners confirmed that cage aquaculture was financially viable even though it is capital intensive. $83.3 \%$ of respondents admitted that they reinvested part of their income in the fish farming projects, while $16 \%$ occasionally reinvested part of their profit in fish farming. The findings suggest that fish farming in floating cages on Volta Lake was financially viable. This explains the purpose of reinvesting gains back into production to expand the industry for more profits. All fish produced in the study region were sold in Ghanaian markets, and none was exported. Tilapia produced in the region has high demand in Ghanaian markets.

\section{Compliance with aquaculture rules in the study region}

Most fish farmers in the study region do not comply with aquaculture rules in Ghana. The Aquaculture Rules of Ghana, 2010 (LI 1968) directs all prospective farmers to acquire three main documents before operating aquaculture projects. These are the acquisition of Environmental Permit from Environmental Protection Agency, Water Use Permit from Water Resources Commission, and Aquaculture Establishment Certificate from the Fisheries Commission. The Abuja Declaration on Sustainable Fisheries and Aquaculture in Africa advocates sustainable aquaculture through integrated water resource management and locally available legislation to protect the environment.

No fish farming entity complied fully with the rules governing aquaculture projects in Ghana. In total, fourteen respondents kept records in different forms, while four had no legal documents to back their fish farming projects. Three fish farming groups had environmental permits, water resource use permits, and aquaculture establishment certificates, and none of the organizations had an environmental management plan (Figure 17). Only one respondent did not provide knowledge and skill training for field workers to safeguard against environmental damage. The rest made provisions for training workshops for their workers.

Challenges facing aquaculture industry in the study region

The farm owners enumerated the challenges facing the aquaculture industry in the study region. These were inadequate capital for investment, high feed prices, mismanagement, poaching, and fish mortality.

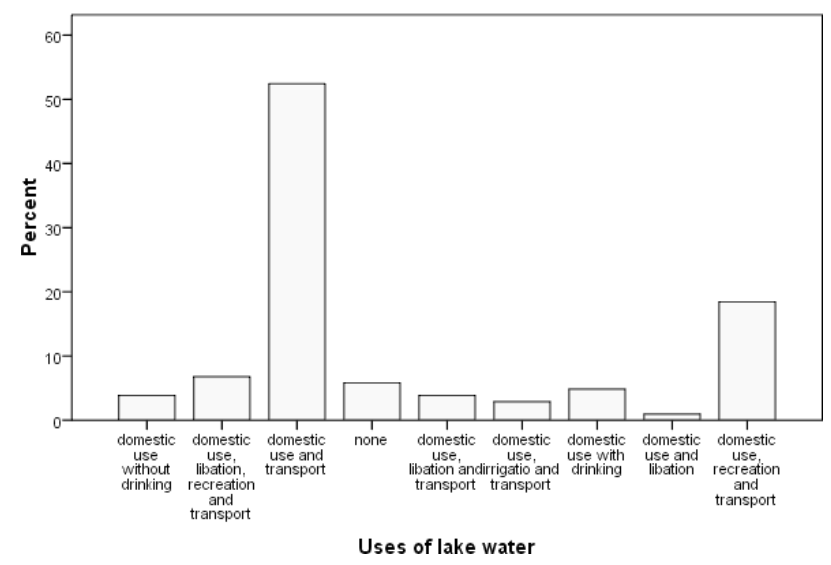

Figure 14. Primary uses of the lake water in the society

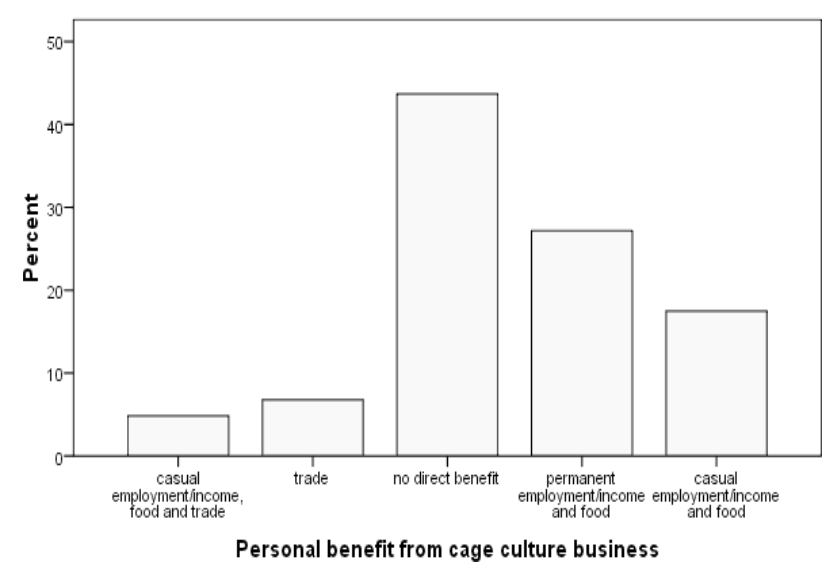

Figure 15. Personal benefits from fish farming 


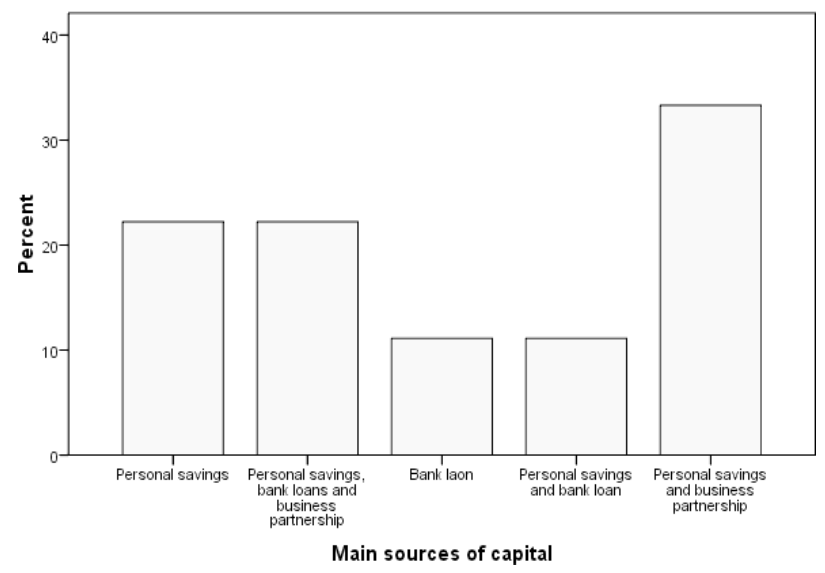

Figure 16. Primary sources of capital for the aquaculture industry

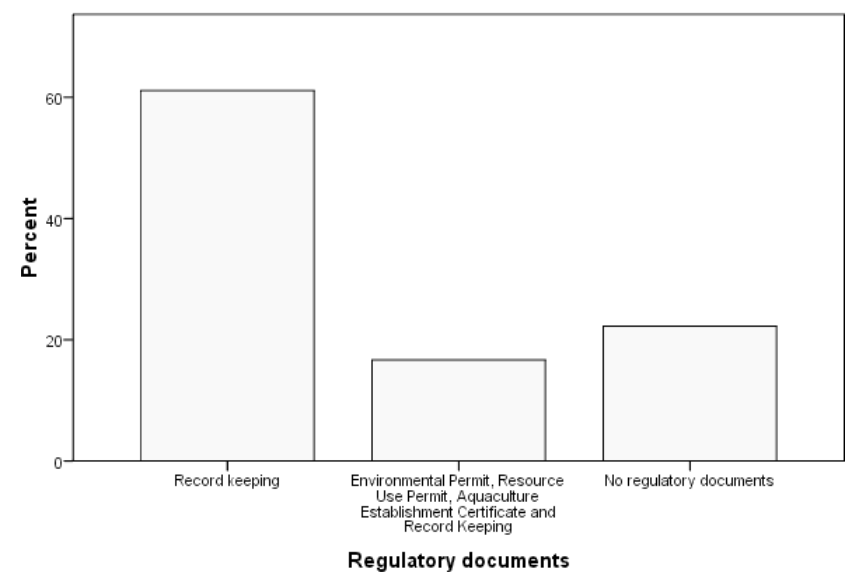

Figure 17. Compliance with aquaculture rules in the study region

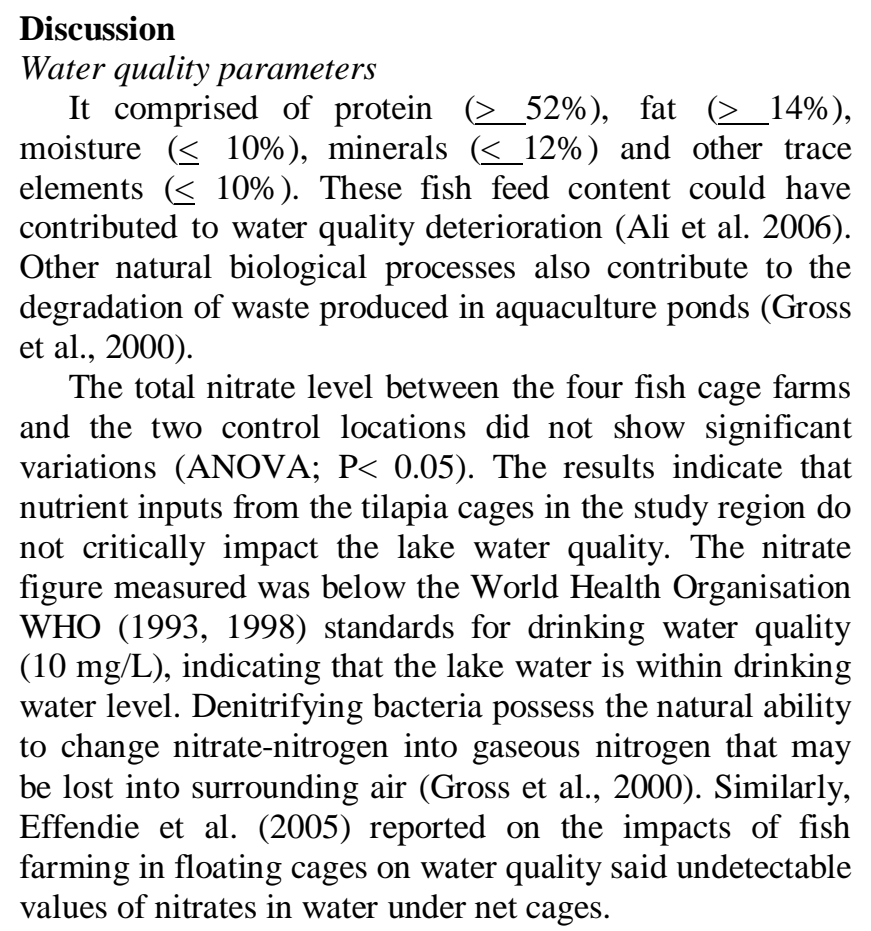

\section{Discussion}

ater quality parameters

It comprised of protein $(>52 \%)$, fat $(>14 \%)$, moisture $(\leq 10 \%)$, minerals $(\leq 12 \%)$ and other trace elements $(\leq 10 \%)$. These fish feed content could have contributed to water quality deterioration (Ali et al. 2006). Other natural biological processes also contribute to the degradation of waste produced in aquaculture ponds (Gross al., 2000). variations (ANOVA; $\mathrm{P}<0.05$ ). The results indicate that nutrient inputs from the tilapia cages in the study region do (he nitrate water level. Denitrifying bacteria possess the natural ability to change nitrate-nitrogen into gaseous nitrogen that may be lost into surrounding air (Gross et al., 2000). Similarly, farming in floating cages on water quality said undetectable values of nitrates in water under net cages.
The phosphate levels in the study region increased slightly in subsequent months from December 2013 to April 2014, with location A maintaining the highest values in all three months. This implies a slight effect of the fish farm at location $\mathrm{A}$ on water quality. The highest recorded amounts of phosphate at location A might be attributed to the higher feed inputs at location $\mathrm{A}$, a region of the lowest depth of the sampling regions at an average of 5.2 meters. The fish farm at location A provided a high quantity of feed (13.8 tons per cage). However, there are no significant differences between cage locations and control locations. Phosphate may be eliminated through adsorbing into water sediments or precipitating directly as insoluble calcium phosphate (CaPO4) from water (Masuda and Boyd 1994).

The average values of ammonium level for all sampling locations showed no significant differences (ANOVA; $\mathrm{P}<$ 0.05 ) between fish farms and control locations. Thus, the results imply that the ammonium level was insignificant in the study region. Water quality in the study region is good compared to WHO and Ghana Standards Authority Water Quality Standards (Table 7). It has the natural ability to assimilate waste products from fish cages (Boyd 2006).

Average DO levels fell at recommended levels for aquatic productivity. The results also suggest fluctuation levels of DO level in the four fish farms and the control locations indicating that the study region was not significantly affected by fish farming activities in the study region. Therefore, significant differences (ANOVA; $\mathrm{P}<$ 0.05) do not exist between the four fish farms and the two control locations. Water currents naturally minimize oxygen depletion in natural waters (Brooks and Mahnken 2003). In previous research, Alston et al. (2005) detected no significant differences in DO levels between cage farms and control locations in Puerto Rican waters.

The $\mathrm{pH}$ value for all the sampling locations during the comparative study was nearly neutral to basic. The finding reveals that the lake water quality is good for aquaculture productivity based on WHO Standards $(\mathrm{pH} 6.5$ - 8.5) and similar to another report by Spicer (1997), which measured the $\mathrm{pH}$ between 6.0 and 8.0. Differences in the results were not significant (ANOVA; $\mathrm{P}<0.05$ ), suggesting that the fish farming activities in the study region did not significantly impact water quality in the region. Helsley (2000) suggested that the environmental impacts of open water aquaculture systems are negligible.

The results show fluctuating figures in the organic matter recorded at the study locations. However, we note that location A recorded the highest levels of organic matter in all three months, indicating higher rates of decomposition in location A, possibly due to higher levels of waste feeds around the location in question. The average values, however, show no significant variations between sampling locations. Turbidity levels varied slightly between the three months but not substantially betweenstudy locations. Turbidity levels fell below WHO (1993, 1998) standards of 5.0, indicating that the water quality in the study region was not affected by fish farming activities.

The results recorded suggest variations in the levels of suspended solids in the study region with time. However, differences between sampled locations were not significant. 
The results support earlier works that found no significant impacts of nutrient inputs from cages on the level of suspended solids in adjacent waters (Pitta et al. 1999, Alston et al. 2005).

Results show no significant differences in total dissolved substances at the six sampling locations. Alston et al. (2005) detected no significant differences between cage farms and the control location. Results in average electrical conductivity values indicate that differences in the electrical conductivity in the study region were not significant. Conductivity was also far below WHO Standards of $700 \mu \mathrm{S} / \mathrm{cm}$ for drinking water. This implies that fish farming in floating cages in the study region has no significant impact on lake water quality.

The average values in copper levels showed no significant variations. The copper level was also below WHO Standards $(2.0 \mathrm{mg} / \mathrm{L})$ for drinking water quality, indicating that the lake water is within drinking water quality and was not significantly affected by fish farming activities in the study region. Copper in specific levels is toxic to some aquatic organisms such as algae and has been used in fish feed formulation to prevent the fungal attack on fishnets (Brooks and Mahnken 2003).

Winsby et al. (1996) detected no difference in copper level in fishnet and a control location of 700 meters away from the fishnet. Nash (2001) also recorded the level of copper in fish cages at levels less than approved standard norms.

Average water temperatures suggest no significant differences between temperature levels at the six sampling locations and that cage aquaculture activities do not significantly impact water temperature levels in the study region. The previous report by Alston et al. (2005) also found no significant differences in water temperatures between fish cages and control locations.

\section{Financial viability of cage aquaculture in the study region}

The records from financial inputs and expenditure in the first production cycle suggested that the average costbenefit ratio of cage aquaculture indicates the industry in the region is financially viable. The differences in profit margins could have been mainly due to differences in stocking density and the amount of fish feed used per cage. It was found that farmers used an imported feed from almost the same sources; feed rationing is different from one fish farm to another. In a report, the FAO (2005) indicated that fish farming provides a significant source of income for farmers in Ghana.

The expected inputs and outputs indicated that the likely average expenditure for the second production cycle was reduced by 32 percent. This was mainly due to fixed data which attracted relatively no cost in the second production cycle. The results also implied that the cage aquaculture industry in Ghana is financially viable with high-profit margins in the second production cycle. Ofori et al. (2009) indicated that farmers in Ghana who averagely produce substantial amounts of fish all year round earn a significant amount of income through the aquaculture industry.

\section{Impact of cage aquaculture on the livelihood of people in} fish farming communities

The figures indicated a substantial youth population in the city $48.5 \%$ of the people interviewed were males, while $51.5 \%$ were females. The ratio reflected the sex composition in the study region. The 2010 population census of Ghana estimated that women constitute $51.3 \%$ of Ghana's population (Ghana Statistical Service 2011).

The study indicated a low level of education in the study region. This is in line with a survey conducted in Bangladesh on the livelihood status of the indigenous people who produced fingerlings for fish farmers and put the people's illiteracy level at $64 \%$ (Gupta and Haque 2011). Another study in Croatia on fish farmers record $3.45 \%$ as fish farmers attaining high schools (Mrcelic and Sliskovic 2010).

The economic activities of the people in the society involved farming, fishing, fish farming, and trading, with a few engaging in artisanship such as carpentry, masonry, and dressmaking. This was an indication that the people's livelihood greatly depended on Volta Lake. Béné and Russell (2007) maintained that a large set of different activities exist even within the same fishing communities along the Volta Lake and emphasized that farming combined with fishing constitutes the most important economic activities in fishing communities.

The majority of the people in a society largely depended on the lake for livelihood purposes, including water transport, recreation, libation (traditional worship), and irrigation. The results suggested that the Volta Lake contributes mainly to the livelihood status of the people in fish farming communities.

The study revealed that $93.2 \%$ of the people in society believed that cage aquaculture does not negatively affect their livelihood opportunities. Only $6.9 \%$ were with the impression that fish farming in floating cages negatively impacts water quality, recreation, and fishing activities. They perceived that the level of cages in the regions affected the lake's beauty and hampered the setting of fish traps in regions close to the shoreline. This indicated that fish farming activities did not negatively impact people's livelihoods of the majority of society members in the study region. The majority thought the water environment was not adversely affected by fish farming in floating cages. This confirmed the assertion that cage aquaculture impacts on the water environment are negligible. According to Pitta et al. (1999), the environmental impacts of cage aquaculture on natural water resources are not statistically significant.

The people's assessment of the attitude of fish farmers in the region towards the water environment was encouraging. This indicated that most of the respondents endorsed how fish farmers handled the environment in the region. The results revealed that fish farming in floating cages has dramatically improved living conditions in society, especially in regions of employment, revenue, food, trade, and poverty alleviation. The society charged a fee before establishing fish cages close to the society. The tax is used for social development. This implies that the 
cage aquaculture industry has positively impacted the livelihood of the people.

The results also indicated that fish farming has benefited individuals in regions of casual employment, permanent employment, income, and fish for household consumption, trade, and poverty alleviation. Women dominated the fish farming activities since their services were more needed during harvesting periods. Women in society are employed for harvesting, conveying, sorting and grading, weighing, fish gutting, recording, and packaging. This helps to improve the economic conditions of women in the study region.

The respondents demanded livelihood assistance from fish farm owners to improve their living conditions. These included the establishment of more fish farms in the region and other livelihood support services such as education, health, road construction, and avoidance of chemical usage in cage aquaculture. The appeal from the society maybe because the society members were aware of the financial gains in the fish farming industry and the fact that the society was deprived of essential amenities.

\section{Aquaculture rules and compliance levels of fish farm owners}

All the fish farm owners interviewed were males, middle-aged people. The finding supports the earlier work conducted by Asmah (2008) that men dominate fish farming in Ghana. Most fish farmers in the study region are highly educated industry.

All the farm owners in the study region engaged in other economic activities apart from fish farming. Precisely, $50 \%$ of the fish farm owners were either government workers or self-employed industry. Fish farming, therefore, was their secondary economic activity. This reveals that most Ghanaians do not regard fish farming as a permanent job, resulting from the fact that the industry venture is capital intensive and associated with a few challenges. Even though many Ghanaians are interested in the aquaculture industry, most people see the industry as part-time economic activity.

Rules on aquaculture in the region were not fully complied with by fish farmers since many fish farms in the study region were operating without registration. Some farmers may also not be aware of the available rules because of the lack of intensive public awareness and education.

Personal savings, bank loans, and individual contributions through industry partnership dominated sources of funding for the aquaculture industry. The findings indicated that sources of financing for aquaculture ventures vary due to their capital-intensive nature. Limited financial resources for aquaculture development in Ghana constraints aquaculture productivity, according to Hiheglo (2008).

All the fish farm owners surveyed agreed that cage aquaculture is financially viable even though it is capital intensive. This is an indication that the fish farming industry in Ghana can contribute mainly to the socioeconomic development of Ghana. Ofori et al. (2009) and
FAO (2005) agree that fish farming generates substantial income for fish farmers.

Most fish farm owners reinvest part of their profits into cage aquaculture. This suggests that fish farming in floating cages on Volta Lake is financially viable. It also shows that fish farmers expand their industry for more profits.

The findings from the study suggest that no fish farmer complied fully with aquaculture rules in Ghana. The Aquaculture Rules of Ghana, 2010 (LI 1968) directs all prospective farmers to obtain three main documents before operating an aquaculture project. These are the acquisition of Environmental Permit from Environmental Protection Agency, Water Use Permit from the Water Resource Commission, and Aquaculture Establishment Certificate from the Fisheries Commission. The Abuja Declaration on Sustainable Fisheries and Aquaculture in Africa also advocates sustainable aquaculture through integrated water resource management and locally available legislation to protect the environment.

Provisions were made for training workshops in cage aquaculture activities for workers. The skill and knowledge training may be helping to reduce the environmental impacts of cage aquaculture on the water environment.

The main challenges recognized with the aquaculture industry in the study region were inadequate capital for investment, high feed prices, mismanagement, poaching, and fish mortality.

This implies that one has to deal with these challenges before the full benefits of aquaculture can be realized. Hiheglo (2008) listed poaching and lack of credit and other financial resources among the challenges facing aquaculture development in Ghana.

\section{Conclusion}

Cage aquaculture is defined by fish farming in floating cages whereby fish and other aquatics are kept in enclosures that permit the exchange of water and waste products between the cage and the water environment around the cage. Cage aquaculture greatly contributes to the socio-economic development in regions of employment, income generation, foreign exchange, and food security. Cage aquaculture adversely impacts the water environment leading to deterioration in water quality. Other experts, however, found no significant effects of cage aquaculture on water quality.

Only less was known of the impacts of cage aquaculture on the Volta Lake and the communities close to cage aquaculture environments. Information on the financial viability of fish farming in floating cages was not readily available in the Ghanaian industry environment. Also, aquaculture regulatory compliance levels were not reported among fish farm owners. The study, thereby, sought to provide answers to these relevant issues.

Kpeve Tornu in the Volta Region of Ghana was chosen as the study region because tilapia cages were densely concentrated in this society. The Ghana Water Company also sourced water from the same region for commercial purposes to serve four administrative districts in the Volta Region. Water samples were taken from four fish farms, 
analyzed, and compared with two control locations between December 2013 and April 2014. Twenty-five percent of adult inhabitants in the society were interviewed to assess the impacts of the fish farming projects on their livelihood opportunities. Five industry entities were selected for data on cost and returns in the cage aquaculture industry for cost-benefit analysis. Sixty percent of fish farm owners were also interviewed to assess the compliance levels with aquaculture rules.

Results showed that significant differences did not exist in water quality parameters at fish farms and control locations. There was also a positive impact of fish farming on members in employment, income generation, and fish for household consumption. The study demonstrated that cage aquaculture was financially viable in Ghana even though it was capital intensive. Aquaculture rules were effective on fingerlings and aquaculture-related chemicals producers. Still, the rules on fish farmers needed a review since there were no definitions for intensive and semiintensive fish farming in the aquaculture rules of Ghana. Compliance levels also required improvement.

\section{REFERENCES}

Ali M, Abdel-Meguid M, Abdin A. 2006. Assessment of floating fish cages impacts on the water, fauna, flora, sediments, aquatic weeds, fish, and hydraulics of Damieta branch. Scientific Bulletin, Faculty of Engineering, Helwan University.

Alston DE, Cabarcas A, Capella J, Benetti DD, Keene-Meltzoff S, Bonnilla J, Cortés R. 2005. Environmental and social impact of sustainable offshore cage culture production in Puerto Rican waters. Final Report 4: 9-12.

APHA-AWWA-WEF. 1998. Standard methods for the examination of water and wastewater, 20th edition. American Public Health Association, Washington DC, USA.

Asmah R. 2008. Development Potential and Financial Viability of Fish Farming in Ghana. [PhD Thesis]. Institute of Aquaculture, University of Sterling.

Béné, C, Russell AJM. 2007. Diagnostic Study of the Volta Basin Fisheries Part 2- Livelihoods and Poverty Analysis, Current Trends and Projections. Report commissioned by the focal basin project Volta. Cairo Egypt: WorldFish Center Regional Offices for Africa and West Asia, 66.

Beveridge M. 1987. Cage Aquaculture. Fishing News Books Ltd, England.

Boyd CE. 2006. Farm-Level Issues in Aquaculture Certification: Tilapia, Auburn, Alabama, USA.

Brooks KM, Mahnken, CVW. 2003. Interaction of Atlantic salmon in the Pacific northwest environment, II. organic wastes. Fish Res 62 (3): 255-293. DOI: 10.1016/S0165-7836(03)00064-X.

Carrol ML, Cochrane S, Fieler R, Velvin R, White P. 2003. Organic enrichment of sediments from salmon farming in Norway: Environmental factors, management practices, and monitoring techniques. Aquaculture 226 (1-4): 165-180. DOI: 10.1016/S00448486(03)00475-7.
Effendie I, Nirmala K, Hasan SU, Sudrajat AO, Muhammad JH. 2005. Water quality fluctuations under floating net cages for fish culture in Lake Cirata and its impact on fish survival. Fish Sci 71 (5): 972-977. DOI: 10.1111/j.1444-2906.2005.01053.x.

FAO. 2005. Yearbook of Fishery Statistics. Food and Agriculture Organization of the United Nations, Rome.

FAO. 2005. Results of the 2003-2004 baseline survey of Ghanaian fish farmers. Food and Agriculture Organization, Accra.

Ghana Statistical Service. 2011. 2010 Population and housing census: Summary report of final results. Ghana Statistical Service, Accra.

Gross A, Boyd CE, Wood CW. 2000. Nitrogen transformations and balance in channel catfish ponds. Aquacult Eng 24 (1): 1-14. DOI: 10.1016/S0144-8609(00)00062-5.

Guo L, Li Z. 2003. Effect of nitrogen and phosphorus from fish cage on the communities of shallow lake in Middle Yangtze River Basin of China. Aquacult 226 (1-4): 201-212. DOI: 10.1016/S00448486(03)00478-2.

Gupta N, Haque M. 2011. Assessing livelihood impacts of cage-based fish fingerlings production on Adivasi households in north-east and northwest Bangladesh. Bangladesh Agricultural University, Mymensingh. DOI: $10.3329 /$ jbau.v9i2.11047.

Helsley CE. 2000. Hawaii open ocean aquaculture demonstration program. European Aquaculture Society Special Publication, Nice, France.

Hiheglo PK. 2008. Prospects, challenges, antidotes, and future prospects of aquaculture in Ghana. Tromso: Norwegian College of Fishery Science, University of Norway. www.ub.uit.no/munin/bitstream/10037/1431/thesis.pdf

Masuda K, Boyd CE. 1994. Phosphorus fractions in soil and water of aquaculture ponds built on clayey, Ultisols at Auburn, Alabama. J World Aquacult Soc 25 (2): 379-395. DOI: 10.1111/j.17497345.1994.tb00223.x.

Mrcelic GJ, Sliskovic M. 2010. The impact of fish cages on water quality in one fish farm in Croatia. World Acad Sci Eng Technol 44: 963966.

Nash CE. (ed). 2001. The net-pen salmon farming industry in the Pacific Northwest. U.S. Dept. of Commer., NOAA Tech. Memo. NMFSNWFSC-46.

Ofori JK, Dankwa HR, Brummet HR, Abban EK. 2009. Producing tilapia in small cages in West Africa. World Fish Center Technical Manual No. 1952. Penang, The World Fish Center.

Phuong NT. 1998. Cage Culture of Pangasius Catfish in the Mekong Delta, Vietnam: Current Situation Analysis and Studies for Feed Improvement. [Ph.D. dissertation]. National Institute Polytechnique, Toulouse.

Pillay TVR. 1992. Aquaculture and Environment. Blackwell Scientific Publications Inc., Cambridge.

Pitta PI, Karakassis M, Zivanovic S. 1999. Natural versus mariculture induced variability in nutrients and plankton in the Eastern Mediterranean. Hydrobiologia 391 (1): 181-194. DOI: 10.1023/A:1003501832069.

Spicer AV. 1997. Water quality for aquaculture. West Virginia University Extension, West Virginia.

United States Department of Agriculture. 2009. Managing Iowa state fisheries: Cage fish culture. Iowa State University, Iowa.

Winsby M, Sander B, Archibald D, Daykin M, Nix P, Taylor FJR, Mundy. 1996. The environmental effects of salmon net-cage culture in British Colombia. Ministry of Environment, Lands and Parks, Environmental Protection Dept. Industrial Waste/Hazardous Contaminants Branch, Victoria, BC.

World Health Organization. 1993, 1998. Guidelines for drinking water quality. WHO, Geneva. 